\title{
ФОЛЬКЛОРИСТИКА
}

\section{Сохранность и изменяемость поэтико-стилевых слагаемых в разновременных записях песни «Шара Гюргю» эпоса «Джангар»}

\section{Байрта Барбаевна Манджиева ${ }^{1}$}

\author{
${ }^{1}$ Калмыцкий научный центр РАН (д. 8, ул. им. И. К. Илишкина, 358000 Элиста, \\ Российская Федерация) \\ кандидат филологических наук, ведущий научный сотрудник \\ (iD) 0000-0002-5644-3340. E-mail: mbbairta@yandex.ru
}

\author{
(C) КалмНЦ РАН, 2021 \\ (C) Манджиева Б. Б., 2021
}

\begin{abstract}
Аннотация. Введение. В системе художественно-изобразительных средств эпитет занимает одно из важных мест. Для создания героического образа сказитель применяет эпитеты, характеризующие статус героя, возраст и героические достоинства богатырей. Цель статьи - изучение художественно-определительных сочетаний — эпитетов - в разновременных записях песни «Шара Гюргю», выявление их сохранности и изменяемости во времени. Для достижения цели решены следующие задачи: выявлены эпитеты в трех разновременных текстах песни «Шара Гюргю» (1862 г., 1970 г., 1971 г.), проведен сравнительный анализ художественно-определительных сочетаний в текстах разных джангарчи. Для изучения поэтико-стилевой фактуры применялся сравнительный метод. Материалом исследования явились разновременные записи: 1) «Песнь о том, как прославленный Улан Шовшур хана мангасов Свирепого Шара Гюргю покорил» Малодербетовского цикла 1862 г.; 2) аудиозапись «Песни о поединке льва[-богатыря] Улан Хонгора Прекрасного со Свирепым Шара Гюргю» джангарчи Телтя Лиджиева 1970 г.; 3) аудиозапись «Песни о Шара Гюргю» джангарчи Михаила Манджиева 1971 г. Результаты. Изучение эпитетов в разновременных записях песни «Шара Гюргю» показало, что за более чем вековой период, прошедший со времени первой записи, эпический текст в своем художественном воплощении подвергся изменениям. Песня «Шара Гюргю» Малодербетовского цикла 1862 г. отличается обилием эпитетов, тогда как в записях поздней традиции эпоса наблюдается трансформация художественного уровня текста. Сказители Телтя Лиджиев и Михаил Манджиев в процессе исполнения придерживаются основной сюжетной структуры, не заостряя внимание на поэтических тропах. Наблюдения над разновременными текстами разных сказителей показывают, что джангарчи, обладая более широким эпическим знанием, исполняет песню в соответствии с критериями верности воспроизведения, следуя традиции той эпической школы, к какой он принадлежал. Сравнительный анализ разновременных записей песни «Шара Гюргю» позволил выявить художественно-определительные единицы на уровне текстового воплощения, которые аккумулируют в себе поэтико-стилевую основу эпического повествования и маркируют ключевые звенья эпического повествования калмыцкого героического эпоса «Джангар».
\end{abstract}


Ключевые слова: эпос «Джангар», джангарчи, цикл, песня, текст, эпитет, разновременные записи, традиция

Благодарность. Исследование проведено в рамках государственной субсидии проект «Устное и письменное наследие монгольских народов России, Монголии и Китая: трансграничные традиции и взаимодействия» (номер госрегистрации: AAAA-A19-119011490036-1).

Для цитирования: Манджиева Б. Б. Сохранность и изменяемость поэтико-стилевых слагаемых в разновременных записях песни «Шара Гюргю» эпоса «Джангар» // Монголоведение. 2021. Т. 13. № 3. C. 553-566. DOI: 10.22162/2500-1523-2021-3-553-566

\title{
The Song of Shara Gürgü: Constance and Variability of Poetic Stylistic Components in Asynchronous Texts
}

\author{
Bayrta B. Mandzhieva ${ }^{1}$ \\ ${ }^{1}$ Kalmyk Scientific Center of the RAS (8, Ilishkin St., 358000 Elista, Russian Federation) \\ Cand. Sc. (Philology), Leading Research Associate \\ iD 0000-0002-5644-3340.E-mail: mbbairta@yandex.ru
}

(C) KalmSC RAS, 2021

(C) Mandzhieva B. B., 2021

\begin{abstract}
Introduction. In the system of artistic and visual means, the epithet occupies one of the important places. To create a heroic image, the narrator uses epithets that characterize the status of the hero, age and heroic merits of the heroes. Goal and tasks. The purpose of the article is to study artistic-identifying combinations - epithets in the recordings of the song "Shara Gyurgyu" at different times, to identify their preservation and change over time. To achieve the goal, the following tasks were solved: epithets were identified in three differenttemporal texts of the song "Shara Gyurgyu" $(1862,1970,1971)$, a comparative analysis of artistic-identifying combinations in the texts of different dzhangarchi was carried out. Method. To study the poetical and stylistic texture, we applied the comparative method. The material of the research was records of different times: 1) "The Song about how the famous Ulan Shovshur of the mangas khan of the Ferocious Shara Gyurgyu reproached the Maloderbet cycle of 1862; 2) an audio recording of "Songs about the duel of a lion [-the hero] Ulan Khongor the Beautiful with the Ferocious Shara Gyurgyu" by Jangarchi Telty Lidzhiev 1970; 3) audio recording of "Song of Shara Gyurgyu" by jangarchi Mikhail Mandzhiev 1971. Results. The study of epithets in recordings of the song "Shara Gyurgyu" at different times showed that over more than a century that has passed since the first recording, the epic text in its artistic embodiment has undergone changes. The song "Shara Gyurgyu" of the Maloderbet cycle of 1862 is distinguished by an abundance of epithets, while in the recordings of the late tradition of the epic, there is a transformation of the artistic level of the text. Storytellers Teltya Lidzhiev and Mikhail Mandzhiev adhere to the main plot structure in the process of performance, without sharpening attention to poetic tropes. Observations of the texts of different storytellers at different times show that Dzhangarchi, having a wider epic knowledge, performs the song in accordance with the criteria of fidelity of reproduction, following the tradition of the epic school to which he belonged. A comparative analysis of recordings of the song "Shara Gyurgyu" at different times allowed us to identify constant units at the level of textual embodiment, which accumulate the poetical and stylistic basis of the epic narrative and mark the key links of the epic narration of the Kalmyk heroic epic "Dzhangar".
\end{abstract}

Keywords: epic "Dzhangar", dzhangarchi, cycle, song, text, epithet, recordings of different times, tradition 
Acknowledgements. The reported study was funded by government subsidy, project no. AAAA-A19-119011490036-1 'Oral and Written Heritage of Mongolic Peoples of Russia, Mongolia and China: Cross-Border Traditions and Interactions'.

For citation: Mandzhieva B. B. The Song of Shara Gürgü: Constance and Variability of Poetic Stylistic Components in Asynchronous Texts. Mongolian Studies (Elista). 2021; 13 (3): 553-566. (In Russ.). DOI: 10.22162/2500-1523-2021-3-553-566

\section{Введение}

В джангароведении, несмотря на разработанность многих аспектов, все еще остаются малоизученными проблемы, связанные с исследованием разновременных текстов калмыцкого героического эпоса «Джангар», анализа их поэтико-стилевых слагаемых. В системе художественно-изобразительных средств эпитет занимает одно из важных мест. Для создания героического образа сказитель применяет эпитеты, характеризующие статус героя, возраст и героические достоинства богатырей. Цель статьи - изучение художественноопределительных сочетаний — эпитетов в разновременных записях песни «Шара Гюргю», выявление их сохранности и изменяемости во времени. Материалом для изучения поэтико-стилевых слагаемых эпоса в разновременных записях «Джангара» явились следующие источники (эпические песни):

1) песня «Догшн Шар Гүргумаңһс хааг дуут Улан Шовшур дөрәиүлгсн бөлг» («Песнь о том, как прославленный Улан Шовшур хана мангасов Свирепого Шара Гюргю покорил») Малодербетовского цикла 1862 г., рукопись К. Ф. Голстунского [Догшн Шар Гүргүһин 1862];

2) аудиозапись песни «Арслнзин Арг Улан Хоңһр Догшн Шар Гүргүлә бәәр бәрлдсн бөлг» («Песнь о поединке льва[-богатыря] Улан Хонгора Прекрасного со Свирепым Шара Гюргю») джангарчи Телтя Лиджиева, запись осуществлена Н. Ц. Биткеевым в июле 1970 г. во время фольклорной экспедиции сотрудников КНИИЯЛИ (КалмНЦ РАН) в совхозе «Эрдниевский» Юстинского района Калмыцкой АССР. Расшифровка фонозаписи Б. Б. Манджиевой (2021 г.) [НА КалмНЦ РАН. Ф. 16. Оп. 1. Фонозаписи. Кассета № 99-100];

3) аудиозапись песни «Шар Гүргүһин бөлг» («Песнь о Шара Гюргю») джангарчи Михаила Манджиева, записана Н. Ц. Биткеевым, Э. Б. Оваловым, Н. Б. Сангаджиевой 24-25 августа 1971 г. в с. Камышево Лиманского района, Астраханской области (расшифровка фонозаписи. Расшифровка фонозаписи Б. Б. Оконова. [НА КалмНЦ РАН. Ф. 16. Оп. 1. Кассета № 112 (121); НА КалмНЦ РАН. Ф. 5. Оп. 2. Ед. хр. 57].

В отечественной науке теоретические подходы в изучении поэтических тропов разрабатывались в трудах известных исследователей: А. Н. Веселовского [Веселовский 1940], Е. М. Мелетинского [Мелетинский 1968], В. М. Жирмунского [Жирмунский 1974], Д. С. Лихачева [Лихачев 1979], Л. И. Тимофеева [Тимофеев 1971], П. В. Палиевского [Палиевский 1979], Б. В. Томашевского [Томашевский 2001], А. И. Алиевой [Алиева 1967; Алиева 1986], А. В. Кудиярова [Кудияров 1984; Кудияров 2002] и др.

По определению А. Н. Веселовского, «эпитет - одностороннее определение слова, либо подновляющее его нарицательное значение, либо усиливающее, 
подчеркивающее какое-нибудь характерное, выдающееся качество предмета» [Веселовский 1940: 73].

Эпитеты являются одним из важнейших изобразительных средств в эпосе «Джангар», которые служат целям раскрытия эпических образов. Рассматривая эпитет в контексте традиции национальных эпосов, Ц. Б. Селеева отмечает, что «устная традиция оперирует фондом канонизированных и традиционных определений, фиксирующих идеальный и типический признак образа или предмета. Эпическому стилю свойственно обилие постоянных эпитетов, придающих повествованию своеобразный украшающий колорит, а также характер типологизации и идеализации» [Селеева 2021: 339].

\section{Эпитеты в разновременных текстах песни «Шара Гюргю»}

Рассмотрим эпитеты, характеризующие главного героя эпоса в разновременных текстах песни «Шара Гюргю».

Малодербетовский цикл (1862 г.)

$950^{1}$ Дала Жаңһрин зергд 'У великого Джангара';

968 Сөң дала хан Жаңһр 'Величия преисполненный хан Джангар’;

1052 Дуут Жаңһһp ‘Прославленный Джангар’;

1140 Алдр нойн Жаңһр 'Славный нойон Джангар';

1335 Нәәтг нойн Жащ̧һр 'Молодой нойон Джангар';

1655 Баатр Жануһp 'Храбрый Джангар';

1672 Һанихн Жаңһр ‘Одинокий Джангар’;

1734 Кишг өргн Жаңһһp 'В благоденствии пребывающий Джангар’;

2156 Нәәхлгсн Жаңһp 'Сомневающийся Джангар';

2264 Аphтахн Жаң̆һp 'Искусный Джангар';

2324 Дольц̧ $р$ Жащ̧һp 'Искушённый в схватках Джангар’;

2349 Дадмг заңзан сургсн Жащ̧һр 'В схватках наторелый Джангар’.

Телтя Лиджиев (1970 г.)

$380^{2}$ Деед богд Жаңһһp 'Верховный богдо Джангар';

450 Дәәнә көлд дассн Жаңһр 'В сражениях закалённый Джангар'.

Михаил Манджиев (1971 г.)

$259^{3}$ Күчтә hарта Жаңһһp 'C сильными руками Джангар';

651 Дольңһр Жаңңһp 'Искушенный в схватках Джангар'.

В тексте Малодербетовского цикла (1862 г.) эпитеты «великий» (дала), «величия преисполненный» (сөщ дала), «славный» (алдр), «прославленный»

${ }^{1}$ В приведенных примерах нумерация обозначает номер строки песни «Догшн Шар Гүргү маңһс хааг дуут Улан Шовшур дөрәцүлгсн бөлг» («Песнь о том, как прославленный Улан Шовшур хана мангасов Свирепого Шара Гюргю покорил») [Джангар 2020: 224-369].

${ }^{2}$ В приведенных примерах нумерация обозначает номер строки в расшифрованной песне «Арслңгин Арг Улан Хоңһр Догшн Шар Гүргүлә бәәр бәрлдсн бөлг» («О поединке Улан Хонгора Прекрасного с Свирепым ханом мангасов Шара Гюргю») джангарчи Телтя Лиджиева [НА КалмНЦ РАН. Ф. 16. Оп. 1. Фонозаписи. Кассета № 99-100].

${ }^{3}$ В приведенных примерах нумерация обозначает номер строки песни «Шар Гүргүһин бөлг» («Песнь о Шара Гюргю») джангарчи Михаила Манджиева [НА КалмНЦ РАН. Ф. 5. ОП. 2. Ед. хр. 57]. 
( основных качеств героя использованы эпитеты, характеризующие: его возраст «молодой» (нәәтг); героические достоинства — «храбрый» (баатр), «искусный» (арhтахн), «искушённый в схватках» (дольңһhp), «в схватках наторелый» (дадмг

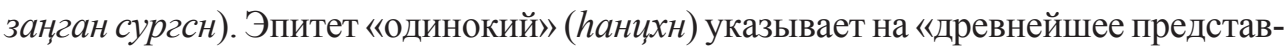
ление об эпическом герое как о первопредке и первом человеке, характерном для эпоса тюрко-монгольских народов» [Кичиков 1992: 8]. В записях поздней традиции эпоса эпитеты, характеризующие Джангара, встречаются крайне редко, - в тексте сказителя Телтя Лиджиева (1970 г.) мы обнаружили только два: «верховный» (деед) и «в сражениях закалённый» (дәәнә көлд дассн), у Михаила Манджиева (1970 г.) встречаются эпитеты, определяющие богатырские качества: «с сильными руками» (күчтә hapma) и «искушенный в схватках» (дольщ̧ $p$ ).

Богатыри эпоса «Джангар», как правило, наделены постоянными эпитетами, которые позволяют выделить самую характерную черту каждого. Для постоянных эпитетов характерна устойчивость, вместе с определяемыми словами они переходят в неизменном виде из одной песни эпоса в другую. Как в Малодербетовском цикле, так и в текстах Телтя Лиджиева и Михаила Манджиева эпитет «мудрый» (күңк) характеризует богатыря Алтан Чеджи, указывая на его незаурядный ум, мудрость, способность предвидеть будущие события и воспроизводить прошедшие.

Рассмотрим эпитеты, выделяющие основные черты одного из главных богатырей Бумбы - Хонгора.

Малодербетовский цикл (1862 г.)

305 Базг Улан Хощ̧һр 'Воинственный Улан Хонгор';

471 ДҮҮвр Хоңһһp 'Гордый Хонгор';

309 Шилвлзгсн Улан Хоңһһp 'Возбужденный Улан Хонгор';

513 Эрвлзгсн Хоңһр 'Проворный Хонгор';

543 Дасгсн Хоңһр 'Привычный Хонгор';

586 КҮмни сәәхн Хощ̧һр 'Несравненный прекрасный Хонгор';

667 Дурта Хоңһһр 'Любимый Хонгор';

702 Зөргтә Хоңһр 'Смелый Хонгор’;

704 Чидлтә Хоңһр 'Сильный Хонгор';

706 Таңсс Хоңһр 'Прекрасный Хонгор';

725 Урдын Улан Хоңһр 'Предводитель Улан Хонгор';

728 ЗҮҮни тоота Хоңһр 'К левой стороне относящийся Хонгор';

756 Залу Улан Хоңһр 'Молодой Улан Хонгор';

1136 Шилвлзгсн Хоңңһp 'Решительный Хонгор';

1163 Бийлә мини әдл Хоңһһp 'Равный мне Хонгор';

1194 Ижсл уга Арг Улан Хоңһһp 'Себе подобных не имеющий Улан Хонгор Прекрасный';

1216 Бийәсн ҮлҮ Арг Улан Хощ̧һр 'Превосходящий [Джангара] Улан Хонгор Прекрасный';

1302 Дуутын Улан Хоңһһ 'Прославленный Улан Хонгор';

1324 Дала Улан Хоџ̧һр 'Великий Улан Хонгор';

1361 Нәәтг Улан Хоң̧һр 'Молодой Улан Хонгор’; 
1373 Көөрк Хощ̧һр 'Дорогой Хонгор';

1612 Арг Улан Хоџ̧һр 'Прекрасный Улан Хонгор’;

1750 Дольц̧һрхн Хощ̧һp 'Искушённый в битвах Хонгор';

2666 Бумбин Хоң̧һр ‘Бумбайский Хонгор’.

Телтя Лиджиев (1970 г.)

43 Әср Улан Хощ̧һр 'Улан Хонгор Необыкновенный';

211 Арслизин Арг Улан Хощ̧һр 'Лев[-богатырь] Улан Хонгор Прекрасный’;

Михаил Манджиев (1971 г.)

230 Арг Улан Хоџ̧һр 'Улан Хонгор Прекрасный';

277 Дольщ̧ $р х х$ Хоң̧һp 'Искушённый в битвах Хонгор'.

В песне Малодербетовского цикла (1862 г.) обнаружилось большое количество эпитетов, используемых для характеристики героя Хонгора как прославленного воина - «великий» (дала), «прославленный» (дуутын); определяющих его статус, его принадлежность — «предводитель» (урдын), «бумбайский» (Бумбин), «к левой стороне относящийся» (зүүни тоота); возраст — «молодой» (улан, нәәтг, залу); богатырские качества — «воинственный» (базг), «смелый» (зөргmә), «сильный» (чидлтә), «решительный» (иилвлзгсн), «искушённый в битвах» (дольңһ $р x н)$, «проворный» (эрвлзгсн), «привычный [к сражениям]» (дасгсн); его превосходство — «себе подобных не имеющий» (ижсл уга), «превосходящий» (бийасн ҮлY); подчеркивающие красоту богатыря - «прекрасный» (арг, таңсс), «несравненно прекрасный» (күмни сәәхн); отмечающие всенародную любовь к Хонгору - «любимый» (дурта), «дорогой» (көөрк); выражающие его характер — «гордый» (дүҮвр), «возбужденный» (иилвлзгсн).

В песне Телтя Лиджиева (1970 г.) присутствуют только четыре эпитета, характеризующие богатыря Хонгора: «необыкновенный» (әср), «молодой» (улан), «лев[-богатырь]» (арслнзгин), «прекрасный» (арг). У сказителя Михаила Манджиева (1971 г.) мы встретили три эпитета: «молодой» (улан), «прекрасный» (арг), «искушённый в битвах» (дольц̧һрхн). Выявление небольшого количества эпитетов в поздних записях «Джангара» указывает на трансформацию поэтико-стилевой фактуры эпического текста. Джангарчи в процессе исполнения песни придерживается основной сюжетной структуры, но художественное воплощение претерпевает изменения.

«Для калмыцкого героического эпоса характерно наличие большого количества эпитетов, указывающих на материал, из которого сделан тот или иной предмет» [Овалов 2008: 245]. Приведем эпитеты, указывающие на материал, из которого изготовлены предметы:

Малодербетовский цикл (1862 г.)

361 Хала мөңзг уудан 'Серебристые удила';

404 Дөл мөңзгн гинжс 'Прочная серебряная дужка [стремени]';

438 Буһ мөнзгн иулвр 'Из оленьей шкуры серебристый повод’;

473 Дег мөнген делтр тальвад [оркхла] 'Серебром расшитый подпотник положили';

475 Тог мөнзгн тохм 'Серебром расшитый потник';

477 Дөш мөнгсн эмәл ‘Как наковальня, широкое посеребрённое седло’; 
428 Хадг алтн ууд 'Прочные золотистые удила';

484 Турмин алтн көвцุ 'Расшитая золотом продолговатая седельная подушка';

487 Цаһан мөнзгн татур 'Серебристая подпруга';

493 Лаң шар алтн омрувчин 'Нагрудника из ланов жёлтого золота';

494 Далн хойр шар алтн товчинь 'Семьдесят две жёлто-золотистые застёжки';

536 КҮрл мөнугн дөрә 'Бронзово-серебряное стремя’;

1011 Кееһин шинжүр мөңзгн ногт 'Нарядный витой серебристый недоуздок';

1012 Шивд мөнцгн хазар 'Серебристая узда';

1017 Шинжур мөңгн ногт 'Витой серебристый недоуздок’;

1019 Сар мөнзгн көмлдрh 'Цвета лунного серебра украшения';

1068 Танчс мөнзгн савхдынь 'Подпруги серебристой концы'.

Телтя Лиджиев (1970 г.)

42 Шуһл мөнзгн иулвр 'Из мягкой кожи серебристый повод';

317 Мөңзгн дөрә 'Серебряное стремя’.

В песне Телтя Лиджиева нами обнаружено всего два эпитета, характеризующих материал, из которого изготовлено конское снаряжение: «из мягкой кожи серебристый повод» (иуһл мөңзгн иулвр), «серебряное стремя» (мөңгн дөрә), а в тексте Михаила Манджиева эпитеты данной группы отсутствуют.

В героическом эпосе «Джангар» присутствует значительное количество эпитетов, придающих образную определенность и указывающих на материал, из которого сделаны предметы.

Малодербетовский цикл (1862 г.)

21 Күжс улан зандар харачлгсн 'С харачи из благовонного красного сандала';

22 Еңзгр изаһан мөңзгәр изаһрглгсн 'С цุагараком из звонкого серебра';

23 Өнчн зандар шуурглгсн 'С шестами из одиноко росших сандалов’;

28 Дарвд алтн хасвчд 'Парадные позолоченные двери';

35 Дөшин шар болд 'Кованые жёлтые булатные мечи';

37 Һулзу мөңгн ииинь 'Изогнутые серебряные рукояти [мечей]';

130 Алтар тавццнгсн 'Из золота основание [столбов]';

131 Зес уга алтар зееглгсн 'Из золота без примеси меди узоры на [столбах]';

132 Зеткр уга ж⿻индмәр кеерүлгсн 'Отводящим беду чиндамани украшен [столб]';

134 Һалвр улан зандар терзлгсн 'Из волшебного красного сандала обрамления окон в нём';

1285 Хатасн хар болд шивә делдв 'Из закалённой стали стены возвели';

1290 Күдр изаһан саадг 'Тугой белый лук';

1357 Ут цุаһан болд 'Длинный булатный меч';

1492 Һалвр зандн терз 'С обрамлением из волшебного сандала окно';

1508 Эр изаһан чолун бәәшң 'Из дикого белого камня дворец';

1840 Эр изаһан чолун шивә кежс 'Из дикого белого камня стену возвели';

1842 Шитм харһа шивә кеж 'Из сосен стеной обнесли';

681 Тог мөнзгн төөрүл 'Круг из чистого серебра'; 
832 Еңзгр мөңзгн бөглә 'Затычка из звонкого серебра';

510 Дөш мөнгг дуулх 'Серебряный шлем’;

1097 Улвр мөңзгн өрүлгтә 'С красноватым отливом с серебристым оперением';

1403 Жинзгл мөңзгн ора 'Навершие серебряного шлема';

1874 Еңзгр мөнцгн изаһрг 'Цагарак из звонкого серебра';

2026 Дөш мөнзгн маңзаһарнь 'Как наковальня, широким лбом’;

114 Дөлдү мөнзгн ширә деер 'Сплошь из серебра на престоле восседая'.

Телтя Лиджиев (1970 г.)

41 Шухр мөнугн ҮҮдн 'Из чистого серебра дверь'.

Михаил Манджиев (1971 г.)

458 Багр мөңгн дегә 'Серебряный крюк';

579 Буһ марльн арсар тулм кеһәд 'Из оленьей шкуры сшил мешок'.

В калмыцком эпосе предметы, изготовленные из серебра, широко распространены. Серебро является благородным металлом, считается, что оно обладает не только очищающими свойствами, но и магической силой, несет в себе защитную функцию - поглощает негативную энергию, не допускает к своему обладателю нечистую силу в виде мусов, шулмусов, всякого рода чудовищ и оборотней. Вследствие этого калмыки широко использовали серебро, что подтверждается присутствием эпитетов данной группы в тексте Малодербетовского цикла: «с цзагараком из звонкого серебра» (ензгр изаһан мөнзгәр изаһрглгсн), «круг из чистого серебра» (тог мөнзгн төөрүл), «затычка из звонкого серебра» (енцгр мөнзгн бөглә), «серебряный шлем» (дөш мөңзгн дуулх), «изогнутые серебряные рукояти [мечей] из звонкого серебра» (һулзу мөңзгн ииинь), «сплошь из серебра на престоле восседая» (дөлдү мөнзгн ширә деер). В тексте Телтя Лиджиева эпитет, обозначающий материал, из которого сделан тот или иной предмет, встречается только один раз: «из чистого серебра дверь» (щухр мөңгн ҮҮдн), а у Михаила Манджиева - идентично: «серебряный крюк» (багр мөнзгн дегә).

В тексте Малодербетовского цикла встречается эпитет золотой, применяемый при описании жилища и его внутреннего убранства: «золотисто-жёлтый дворец» (алтн шар бәәшң), «из золота основание [дворца]» (алтар тавцңнгсн), «из золота без примеси меди узоры на нем» (зес уга алтар зееглгсн), «парадные позолоченные двери» (дарвд алтн хасвч). Эпитет «золотой» (алтн ширә 'золотой трон', алтн эмәл 'позолоченное седло') не только указывает на лучший материал, подчеркивает ценность и красоту вещей, но и имеет переносный смысл, поскольку использование золота при изготовлении изделий в эпическом тексте означает святость их обладателя. В тексте джангарчи Телтя Лиджиева эпитет «золотой» встречается всего четыре раза: «золотой шлем» (алтн дуулх), «священный локоть» (алтн тоха), «золотой дворец» (алтн бәәшң) и «золотая раковина» (алтн дуц̧г), у Михаила Манджиева — два раза: «золотое молозиво» (алтн уург) и «золотой клык» (алтн аран). В описании жилища и крепости в Малодербетовском цикле применяются и другие эпитеты: «из дикого белого камня дворец» (эр цчаһан чолун бәәшң), «отводящим беду чиндамани украшен [дворец]» (зеткр уга жсиндмәр кеерүлгсн), «из дикого белого камня стена» (эр 
цุаһан чолун шивә), «сосновая стена» (шитм харһа шивә), «из закалённой стали стены» (хатасн хар болд шивә), «с обрамлением из волшебного сандала окно» ( меч»: «кованые жёлтые булатные мечи» (дөшин щар болд), «длинный булатный меч» (ут изаһан болд).

Для создания ярких образов эпических персонажей, описания предметов и явлений природы джангарчи применяют эпитеты, в состав которых входят колоронимы. Рассмотрим данную группу эпитетов.

\section{1) белый цвет (цаһан)}

\section{Малодербетовский цикл (1862 г.)}

11 Бумбин цаһан өргәг 'Бумбайский белый дворец';

48 Тальвин цзаһан хурлнь 'Просторный белый хурул';

348 Нәрн изаһан дууһар хәәкрәд 'Зычным голосом крикнув';

366 Дунъва изаһан һууртан 'На цвета раковины белое запястье';

503 Дөш ияаһан биизән өмсв 'Широкое белоснежное бизе надел';

720 Уm изаһан болдан 'Длинный белый булатный меч';

959 Күңґ изаһан ухандкан 'Тем, что терзает ваш светлый ум';

1144 Арвн цзаһан ясн 'Священным костям моим';

1269 Хоңһһрин күңзк иุаһан ухань 'Хонгора ясный светлый разум';

1290 Күдр иุаһан саадг 'Тугой священный лук’;

1550 Эж⿻го эрм изаһан көдәд 'В безлюдной пустынной степи'.

Телтя Лиджиев (1970 г.)

83 Эж⿻го эрм изаһан көдәд 'В безлюдной пустынной степи';

134 Цаһан өргә 'Белый дворец';

376 Сольр нүдтә хомха иุаһан эмгн 'Косоглазая бледная старуха';

425 Ооср уга хо ичаһан өргә 'Белая кибитка без веревок-креплений’.

Михаил Манджиев (1971 г.)

9 Күнък ияаһан ухаһан 'Тем, что терзает ваш светлый ум';

22 Күнък изаһан чеежсәрн 'Тем, что терзает вашу светлую душу’;

57 Жидл иаһан бергән 'Светлоликую жену старшего брата';

68 Хагсуһин циаһан шиль 'Безводная белая степь';

100 Арвн ияаһан ясинь 'Священные кости его';

339 Эр изаһан чолун шивә кежс 'Крепость из белого камня';

430 Баатр ияаһан арсн хуйг болжс хүврәд 'Богатырское белое тело в дырчатую кольчугу превратилось';

823 Үйин ц̧аһан эмән түркәд 'Священным снадобьем помазав'.

\section{2) желтый цвет (иар)}

Малодербетовский цикл (1862 г.)

62 Өрин улвр шар нарн 'На рассвете плавно жёлтое солнце';

65 Тамбл шар нарн 'Яркое жёлтое солнце';

236 Шар ияоохр итлг ‘Желто-пёстрый балобан';

479 Зууһнн шар алтн худрh 'C пластинами из освященного жёлтого золота подхвостник'; 
493 Лаң шар алтн омрувчин 'Нагрудника из ланов жёлтого золота'; 570 Шар цุоохр олнизг 'Жёлто-пёстрые тебеньки';

625 Шар цүоохр луви ‘Жёлто-пёстрый панцирь';

915 Нәрхн шар алтн ятх 'К изящной жёлто-золотистой ятхе';

923 Шар алтн иуурар 'На жёлто-золотистом иуре';

936 Делкән шар нарн 'Вселенское желтое солнце';

1727 Әгр шар керсн урһад бәәж ‘Выгоревшей жёлтой лебедой всё поросло’.

Телтя Лиджиев (1970 г.)

436 Билгин шар болд үлдән 'Волшебный желтый булатный меч';

627 Шар иидмс 'Жёлтые путы';

698 Шар цุоохр бәәшңдән 'В жёлто-пёстром дворце своем'

Михаил Манджиев (1971 г.)

470 Шар-иоохр тугин йозурт 'У жёлто-пёстрого знамени'.

\section{3) красный цвет (улан)}

Малодербетовский цикл (1862 г.)

18 Мал улан ширәр ширдгсн 'Масляной красной краской покрашенный';

21 Күжу улан зандар харачлгсн 'С харачи из благовонного красного сандала';

263 ГүУдг улан тоосан алдад ж⿻иңнв 'Красноватую пыль [столбом] поднимая, помчались [они]';

356 ЗҮҮдн улан көөсән цุацад 'Небывало красную пену разбрасывая';

424 Бальнн улан өвдг 'К багровому колену';

636 Маш улан хачр гүвдәд 'В бесподобно алую щёку ударяясь';

809 Минт мет улан урлта 'Пухлые алые губы у неё';

1228 Улан чиг өсртл татад 'Красные искры [от неё] летели';

1402 Улан цุоохр тугичн хуһлад 'Красно-пёстрое знамя твоё изломав’;

2190 Зандн улан цүог улаһад бәәнә 'Очаг цвета сандала угольями краснеет';

2260 Илвин гүңбин улан уут 'Колдовской красный мешок'.

Телтя Лиджиев (1970 г.)

18 Улан әркән 'Красное вино';

40 Миимин улан һосарн 'Мягкими красными сапогами';

210 Алвтнь мөңзгн улан хаалһ болжс үлдв 'Во владении красная дорога лишь осталась';

578 Улан тоосн 'Красная пыль';

620 Уйн улан бүснь 'Красный пояс'.

Михаил Манджиев (1971 г.)

58 Цусн улан күҮкән 'С румяным лицом дочь';

802 Догшн улан теңзгсин көвәд 'На берегу бурного красного моря'.

\section{4) черный цвет (хар)}

Малодербетовский цикл (1862 г.)

629 Хар гижсгнь 'Черная коса';

645 Мөсн хар нүднь 'С холодным взором чёрные глаза';

893 Заңзгин хар дала 'Бурный чёрный океан';

1147 Альвн хар сүмсн 'Грешной душе моей';

1920 Байн хар иуснь 'Обильно пролитая тёмная кровь'; 
2483 Харщ̧һу хар там орн сәнжс 'Тёмной преисподней это место оказалось'; 2525 Хар тензгс 'Черное море'.

Телтя Лиджиев (1970 г.)

189 Хар иุоохр күлгиннь 'Чёрно-пёстрого скакуна';

720 Догшн хар тензгс ‘Бурное черное море’.

Михаил Манджиев (1971 г.)

429 Байн хар иусни 'Обильная чёрная кровь';

628 Хар уури 'Черная лачуга';

777 Харцһһ хар тамин орн 'Темное подземелье'.

Эпитеты, обозначающие цвета «белый», «желтый», «красный», в основном имеют положительную оценку чего-либо в эпосе. Эпитет «белый» полисемичен, имеет значения «священный», «чистый»: «священные кости» (арвн цุаһан ясн), «священный дворец» (цаһан өргə), «просторный священный хурул» (тальвин цุаһан хурлнь), «ясный чистый ум» (күньк цุаһан ухан), «священный лук» (цаһһан саaд).

Эпитет «желтый» передает как положительное качество предмета: «жёлтое солнце» (иар нарн), «из освященного жёлтого золота» (зууһин шар алтн), «жёлтое золото» (шар алтн), «жёлто-золотистая ятха» (шар алтн ятх), — так и оценочные значения, усиливающее отрицательное содержание определяемого слова: «жёлтая лебеда / выгоревшая трава» (щар керсц).

Красный цвет в словосочетаниях улан арз ('крепкая арза'), улан тоорм ('столб красной пыли'), улан агт ('прекрасные скакуны'), улан шүҮсн ('красная сукровица'), улан цุог ('красные угли) символизирует крепость, силу, огонь, тепло и т. п.

Эпитет хар ('черный') в ряде случаев употребляется в значении «чистый», например, хар нульмсн ('прозрачные слезы'), хар арз ('прозрачная арза'), а также как показатель «прочности» хар болд max ('прочные подковы'). Эпитет xap ('смуглый’) в имени богатыря Санала характеризует его богатырскую силу.

Постоянными эпитетами наделены в песне богатырские кони: арнзл (“боевой’); сәәхн ('прекрасный’); хурдн ('резвый’). Эпитеты часто используются и при описании внешнего вида коней, что придает им индивидуальные черты. Так, конь Джангара имеет «золотистые уши», «взгляд острый, соколиный».

Для стилистики песни Малодербетовского цикла характерно также наличие эпитетов метафорического значения: шур болгсн сәәхн сүүлтә ('с коралловым отливом красивый хвост'), эрднь хурин салькн ('ветер, что несет драгоценный дождь’); эрднь билгин хурнь ('драгоценный благодатный дождь’); эрднь хамmхасн ('драгоценные листья').

В песне присутствуют постоянные определения, переходящие в устойчивые эпитеты: усн уга шал ('безводная белая степь'); өвсн уга цөл ('пустыня без травы’); көк девән өвсн ('зеленая луговая трава') и др. Эта группа устойчивых эпитетов отражает в известной мере круг наблюдений скотовода-кочевника, жизнь которого была неразрывно связана со степью, ее природными и климатическими условиями. 


\section{Заключение}

Анализ поэтико-стилевых слагаемых в разновременных текстах песни «Шара Гюргю» показал, что ранняя запись 1862 г. Малодербетовского цикла отличается обилием эпитетов, характеризующих статус хана Джангара, возраст и героические достоинства богатырей, тогда как в записях поздней традиции эпоса эти эпитеты встречаются редко. Сказители Телтя Лиджиев и Михаил Манджиев в процессе исполнения придерживаются основной сюжетной структуры, не заостряя внимание на поэтических тропах. Для описания героя эпоса джангарчи Малодербетовского цикла использует эпитеты, характеризующие возраст богатыря, его достоинства, в записях поздней традиции они встречаются крайне редко. В текстах песен встречается также значительное количество эпитетов, придающих образную определенность и указывающих на материал, из которого сделаны предметы. В текстах трех песен сказители применяют эпитеты, в составе которых цвета «белый», «желтый», «красный», преимущественно имеющие позитивную оценку чего-либо в эпосе или отмечающие положительное качество предмета.

Изучение эпитетов в разновременных записях песни «Шара Гюргю» показало, что за более чем вековой период, прошедший со времени первой записи, эпический текст в своем художественном воплощении подвергся изменениям. Но при всем этом выявленные нами изменения не могут свидетельствовать о затухании или ослаблении эпической традиции, потому как «певец прежде всего хранитель эпического знания» [Гацак 1971: 45]. Наблюдения над разновременными текстами разных сказителей показывают, что джангарчи, обладая широким эпическим знанием, исполняет песню в соответствии с критериями верности воспроизведения, следуя традиции той эпической школы, к какой он принадлежал. Сравнительный анализ разновременных записей песни «Шара Гюргю» позволил выявить художественно-определительные единицы на уровне текстового воплощения, которые аккумулируют в себе поэтико-стилевую основу эпического повествования и маркируют ключевые звенья эпического повествования калмыцкого героического эпоса «Джангар».

\section{Источники}

Джангар 2020 - Калмыцкий героический эпос «Джангар»: Малодербетовский цикл / вступ. ст. Б. Б. Манджиевой; сверка текстов песен с оригиналом на «ясном письме» Б. Б. Горяевой, Б. Б. Манджиевой, Ц. Б. Селеевой; пер. Т. А. Михалевой; примеч., коммент., словарь, указатели Б. Б. Манджиевой, Т. А. Михалевой; отв. ред. Г. Ц. Пюрбеев, С. Ю. Неклюдов, В. В. Куканова. М.: АО «Первая Образцовая типография», Филиал «Чеховский Печатный Двор», 2020. 544 с.

Догшн Шар Гүргүһин 1862 - Догшн Шар Гүргүһин бөлг (= Песнь о Свирепом Шара-Гюргю) // Рукописный отдел библиотеки Восточного факультета СПбГУ. Calm. C. 4. Inventory No. 1834. Old call number XylQ 544. Golstunsky Collection (1862), No. 3. Л. 1-30. Рукопись на ойратском письме.

НА КалмНЦ РАН - Научный архив Калмыцкого научного центра РАН.

\section{Sources}

Kalmyk Heroic Epic of Jangar: The Baga Dorbet Cycle. B. Mandzhieva (foreword), etc. G. Pyurbeev, S. Neklyudov, V. Kukanova (eds.). Moscow: Chekhovskiy Pechatnyi Dvor (Pervaya Obraztsovaya Tipografiya), 2020. 544 p. (In Kalm. and Russ.) 
Kalmyk Scientific Center (RAS), Scientific Archive. (In Kalm.)

The Song of Shara Gyurgyu the Furious. Manuscript. At: St. Petersburg State University, Faculty of Asian and African Studies, Manuscript Department. Calm. C. 4. Inventory no. 1834. Old call number XylQ 544. Golstunsky Collection (1862), no. 3. Pp. 1-30. (In Oir.)

\section{Литература}

Алиева 1967 - Алиева А. И. Эпитет в адыгском героическом эпосе // Ученые записки Кабардино-Балкарского НИИ. Серия филологическая. Т. 24. Нальчик, 1967. С. 17-18.

Алиева 1986 - Алиева А. И. Поэтика и стиль волшебных сказок адыгских народов. М.: Наука, 1986. 278 с.

Веселовский 1940 - Веселовский А. Н. Историческая поэтика. Л.: Гослитиздат, 1940. $364 \mathrm{c}$.

Гацак 1971 - Гацак В. М. Эпический певец и его текст // Текстологическое изучение эпоса. М.: Наука, 1971. С. 7-46.

Жирмунский 1974 - Жирмунский В. М. Тюрскский героический эпос. Л.: Наука, 1974. $726 \mathrm{c}$.

Кичиков 1992 - Кичиков А. Ш. Героический эпос «Джангар». Сравнительнотипологическое исследование памятника. М.: Наука, Вост. лит., 1992. 320 с.

Кудияров $1984-$ Кудияров $A$. В. Художественно-стилевые закономерности эпоса монголоязычных народов // Фольклор. Образ и поэтическое слово в контексте. М.: Наука, 1984. С. 10-57.

Кудияров 2002 - Кудияров А. В. Художественно-стилевые традиции эпоса монголоязычных и тюркоязычных народов Сибири. М.: ИМЛИ РАН, 2002. 327 с.

Лихачев 1979 - Лихачев Д. С. Поэтика древнерусской литературы. М.: Наука, 1979. $352 \mathrm{c}$.

Мелетинский 1968 - Мелетинский Е. М. Эдда и ранние формы эпоса. М.: Наука, 1968. $368 \mathrm{c}$.

Овалов 2008 - Овалов Э. Б. Сюжетно-стилевые традиции в эпосе «Джангар» и его версиях. Элиста: АПП «Джангар», 2008. 304 с.

Палиевский 1979 - Палиевский П. В. Литература и теория. М.: Сов. Россия, 1979. 288 с.

Селеева 2021 - Селеева Ц. Б. Типизирующая роль эпитетов в стилистике синьцзянойратской версии «Джангара»// Новый филологический вестник. 2021. № 1(56). C. 337-349. DOI: 10.24411/2072-9316-2021-00026

Тимофеев 1971 - Тимофеев Л. И. Основы теории литературы. М.: Просвещение, 1971. $464 \mathrm{c}$.

Томашевский 2001 - Томашевский Б. В. Теория литературы. Поэтика. М.: Аспектпресс, 2001. 334 с.

\section{References}

Alieva A. I. Epithet in Adyghe heroic epic. In: Kabardino-Balkaria Research Institute. Scholarly Notes. Ser. 'Philology'. Vol. 24. Nalchik, 1967. Pp. 17-18. (In Russ.)

Alieva A. I. Magic Tales of Adyghe Peoples: Poetics and Style. Moscow: Nauka, 1986. 278 p. (In Russ.)

Gatsak V. M. Singer of epic poems and his text. In: Textology of Epic. Moscow: Nauka, 1971. Pp. 7-46. (In Russ.)

Kichikov A. Sh. Heroic Epic of Jangar: A Study in Comparative Typology. Moscow: Nauka: Vostochnaya Literatura, 1992. 320 p. (In Russ.)

Kudiyarov A. Epic of Siberian Turko-Mongols: Artistic and Stylistic Traditions. Moscow: Gorky Institute of World Literature (RAS), 2002. 327 p. (In Russ.)

Kudiyarov A. V. Epic traditions of Mongols: Artistic and stylistic patterns. In: Folklore. Image and Poetic Word in Context. Moscow: Nauka, 1984. Pp. 10-57. (In Russ.)

Likhachev D. S. Poetics of Old Russian Literature. Moscow: Nauka, 1979. 352 p. (In Russ.) 
Meletinsky E. M. Edda and Early Forms of Epic. Moscow: Nauka, 1968. 368 p. (In Russ.)

Ovalov E. B. Epic of Jangar and Its Versions: Traditions of Plot and Style. Elista: Dzhangar, 2008. 304 p. (In Russ.)

Palievsky P. V. Literatura and Theory. Moscow: Sovetskaya Rossiya, 1979. 288 p. (In Russ.)

Seleeva Ts. B. The typical role of epithets in the stylistics of the Xinjiang-Oirat cersion of the

'Dzhangar'. The New Philological Bulletin. 2021. No. 1 (56). Pp. 337-349. (In Russ.) DOI: 10.24411/2072-9316-2021-00026

Timofeev L. I. Foundations of Theory of Literature. Moscow: Prosveshchenie, 1971. 464 p. (In Russ.)

Tomashevsky B. V. Theory of Literature: Poetics. Moscow: Aspect-Press, 2001. 334 p. (In Russ.)

Veselovsky A. N. Historical Poetics. Leningrad: Goslitizdat, 1940. 364 p. (In Russ.)

Zhirmunsky V. M. Turkic Heroic Epic. Leningrad: Nauka, 1974. 726 p. (In Russ.) 